\title{
Perception of urban safety: the case of Lublin, Poland
}

\section{Abstract}

The aim of the study was to evaluate safety and its underlying factors among the inhabitants of Lublin. The findings are based on a questionnaire with 33 detailed questions conducted in May 2012 in all districts of the city. The collected data from the survey and Voivodeship Police Department in Lublin was analysed using ArcGIS and STATISTICA software. The analysis of the crime data shows the existence in the city of a clear zone of increased risk of crime occurrence. The survey showed that, in the last 10 years, approximately $28.1 \%$ of the responding inhabitants of Lublin have been victims of a crime in the city. Statistical analysis of the results revealed a statistically significant correlation between people's evaluations of safety in Lublin districts and their age, gender, income, place of residence, quality of life, and participation in public life.

Keywords

Eastern Poland $\bullet$ Lublin $\bullet$ crime $\bullet$ living safety $\bullet$ crime geography

(c) University of Warsaw - Faculty of Geography and Regional Studies

\author{
Viktoriya Pantyley', Jolanta Rodzoś ${ }^{2}$, \\ Mateusz Piskorski ${ }^{3}$ \\ 'Department of Socio-Economic Geography \\ Faculty of Earth Sciences and Spatial Management \\ Maria Curie-Skłodowska University in Lublin, Poland \\ e-mail: wiktoria.pantylej@poczta.umcs.Iublin.pl \\ ${ }^{2}$ Geography Learning Laboratory Faculty of Earth \\ Sciences and Spatial Management \\ Maria Curie-Skłodowska University in Lublin, Poland \\ e-mail: jolanta.rodzos@poczta.umcs.lublin.pl \\ ${ }^{3}$ Marshal Office of Lubelskie Region, Poland \\ e-mail:mateusz.piskorski@wp.pl \\ Received: 1 September 2016 \\ Accepted: 31 December 2016
}

Introduction

The nature of social and economic transformations currently occurring in the world is drawing the attention of various circles to safety issues. In the era of free access to goods and services, this has become a limited category, particularly in urban spaces which offer residents enormous possibilities to satisfy their needs, but which are simultaneously becoming very unfriendly spaces with a high risk of the occurrence of criminal phenomena. The problem of crime is important from the individual perspective as an element affecting the living situation of individuals. It is also a factor determining the development perspectives of a given area. Threats occurring in an urban space reduce its attractiveness, and therefore affect the decisions of residents as well as potential investors. Attractiveness is a feature determining the broadly defined motivational domain, providing the basis for the decisionmaking processes of individuals and larger groups choosing places for particular types of activity. Such decisions not only have financial repercussions, but also determine many social processes, such as the development of residents' spatial identity and the identity of the urban space.

Sustainable urban development and the provision of safe living conditions are among the EU priorities for the 2014-2020 perspective. Lublin, a city with 326,276 inhabitants, is the capital of Eastern Poland, which is a border region of the European Union. Although the crime rate in Lublin is relatively low compared to other Polish cities, only $42 \%$ of crimes are reported here - the worst rate in Poland (Siemaszko 2009).

The general objective of this paper is the assessment of the level of safety in Lublin in terms of spatial diversity. It involves conducting a comprehensive analysis of criminal phenomena in Lublin and their distribution, based on data obtained from the Voivodeship Police Department in Lublin. Because the phenomenon of safety also has a subjective dimension, an analysis of the feeling of safety of residents will also be performed, based on data collected in the course of the authors' own field research in the territory of Lublin. The results of the research, based on both groups of data (objective and subjective), will be compared to allow for the identification of areas of assessment inadequate to the actual level of safety.

Theory of fear of crime and perceived safety among the city's inhabitants: the global dimension

Research on crime and conditions of city inhabitants' safety of living is conducted at the boundary of many different scientific disciplines: criminology, psychology, sociology and criminal geography. The following areas of interest are distinguished within crime geography: the spatial variability of crime, places of origin and characteristics of criminals, police actions or perception of crime and fear of crime (Guzik 2000).

Analysis of the spatial aspects of crime has been conducted in Europe since the $19^{\text {th }}$ century. A. M. Guerry (1833) conducted an analysis of France according to types of crime, sex and age of criminals, level of education and social status of the population, and according to the number of suicides. In 1842, A. Quetelet, in his work "A treatise on men", based on data from French police records, drew a conclusion about the uneven spatial distribution of crime in France. These findings were the basis for further research on crime in Europe. (Chainey \& Ratcliffe 2005).

At the beginning of the $20^{\text {th }}$ century in the USA the most famous of its achievements was the Chicago School of Criminology (1920-1940; C. Shaw and H. McKay). The most significant 
contribution of this school was the concept of social ecology. One of their primary arguments was that economic crises, immigration and family instability tend to cause crime. Researchers from the Chicago School of Criminology were able to study in detail the differences in crime between the rich Chicago suburbs and the poor inner city. According to Treadwell (2006), among the main contributions of this school were the qualitative research methods used, such as direct interviews with subjects.

The interest of researchers in this issue reaches back to the 1970 s, with the commencement of studies on the determination of correlations between crime and its spatial distribution and variability. Such analyses were performed first in the United States, and later in Western Europe (Fyfe 2000). They concerned attempts to correlate regional aspects of crime with features of the physical and social environment of the life of the inhabitants. The application of crime surveys in the 1970s, based on interviews with victims of crimes, permitted the identification of dangerous places with higher precision, and facilitated the preparation of detailed maps of these places (Smith 1987). The modern development of GIS also permitted advanced research on the spatial aspects of crime, and the identification of so-called "hot spots" - areas generating the highest number of police reports (Ashby \& Craglia 2007).

According to Fyfe (2000), traditional crime geography focuses on the narrow issue of mapping crime, and on the delimitation of crime areas. It rarely refers to broader issues related to the consequences of crime or its control, or to broader social-political analysis. In the last 40 years of the $20^{\text {th }}$ century in Western Europe and on the American continent, papers appeared focusing on the consequences of crime and the perception of fear and safety (Smith 1987; Valentine 1992; Pain 2001). In a broader context, modern crime geography has been transformed from a narrow sub-discipline analysing dangerous areas in terms of crime into a modern field of science which also addresses the spatial aspects of fear, safety and social control.

Papers by Wang and Minor (2002) show correlations between crime and unemployment in the city (an increase in crimes on property, and not threatening human health or life). In their research, Ceccato et al. (2002) discovered that the highest concentration of crime occurs in city centres. This concerns the administrative centre, but also areas of entertainment where the life of young people is particularly concentrated. According to Ceccato et al. (2002), crime is also related to other parts of the city where social problems occur. Another example of spatial analysis is the paper by Ackerman \& Murray (2004) presenting an analysis at three scales for one city - at the macro scale (identification of problem areas), at the meso scale (quality analysis), and at the micro scale (determination of the correlation of crime with social structure). Malczewski and Poetz (2005) determined that burglary usually occurs in areas with multi-family housing with a high real estate value. Interesting conclusions were provided by research conducted at the beginning of the $21^{\text {st }}$ century in Great Britain, called the reassurance paradox (Crawford 2006). According to the term, irrespective of decreasing crime rates and an increase in the number of police services, social lack of safety and fear of crime tend to remain at a very high level.

Concepts appeared for various perceptions of places, such as topophilia (favourite places) and topophobia (unpleasant, dangerous places) (Smith et al. 2010). Tuan (1979) introduced the concept of landscapes of fear. The geography of fear assumes that the feeling of the threat of crime experienced by people using public spaces in a city is manifested in special terms by their conscious avoidance of certain public places at specific times of day (Madge 1997). In modern humanist geography, the conceptualisation of the term "fear" has been introduced and shown in a 3-dimensional perspective: from the point of view of place, personality, and fear itself (through a phobia, experience, and memory) (Smith et al. 2010).

In his paper on social and cultural significance in the fear of crime, Jackson (2004) examined links between community cohesion, disorder and crime. According to his research, perceptions of risk depend on individuals' understanding of the social and physical environment in their neighbourhood, on their personal social values, and on vulnerability. Jackson suggested that the prevalence of the fear of crime in survey responses was exaggerated due to the 'experience' fear of the respondents and 'expressive' fear, which is caused by social relations and conditions leading to crime or the cultural meaning of crime (Jackson 2004, p. 963). In another work, Jackson (2008) argued that a comprehensive account of the fear of crime needs to bridge psychological and sociological levels of analysis. From his perspective, "Rather than fear of crime being solely about crime, it encompasses and expresses a whole set of public perceptions of symbols of crime... people identify things in their community that are hostile to social order; they designate these as representative of criminal threat; and they identify individuals, behaviours and communities as somehow lacking - on the wrong side of acceptability" (Jackson 2008, p. 144). Perceived vulnerability to victimization is a key element in the fear of crime. For example, more serious consequences are expected to occur in the case of women, elderly people and those in bad health, as well as among those without social support and living in remote areas. However, the weak correlation between fear and the risk of crime creates the risk-fear paradox: "more people worry about crime than are likely to fall victim and the wrong people seem to be worrying" (Jackson 2008, p. 152). A recent paper by Ceccato and Bamzar (2016) focuses on elderly victimization and their fear of crime in public spaces in Stockholm, Sweden. They find that elderly victimization and fear of crime are associated with particular features of the local urban environment. Although elderly people are at less risk of being victimized, they are more likely to be fearful in comparison with the other age groups of the population.

Theory of fear of crime and perceived safety among city inhabitants in Poland and Eastern European countries

Safety and sustainability in a city is one of the most important elements in sustainable urban development. In the analysis of urban safety, researchers often link fear of crime to indirect victimization, vulnerability and community concern (Ceccato \& Lukyte 2011). Studies at regional levels in Russia and Eastern Europe suggest that social stress and a long-lasting transition period are related to increased number of suicides, homicides, violence and various property crimes (Ceccato 2008; Andresen 2009). Fear of crime is also influenced in these countries by the confidence in policing, and certain macro factors at the national and global levels, such as the media. Studies concerning crime distribution in the postsocialist states of Estonia, Latvia and Lithuania showed increased rates of homicide in these countries in comparison with Western European countries (Ceccato 2008). Reporting rates are higher in Western European cities, where half of the incidents were reported, while in Eastern European cities only one third of crime incidents were reported. In addition, property crimes are more frequently reported than other types of crime (Ceccato \& Lukyte 2011). It seems that underreporting is worse in countries with unreliable police and justice systems, significant corruption and high social inequalities (Fajnzylber, Lederman \& Lloayza 2002).

In Poland, detailed analyses of crime were initiated in the 1990s. Mordwa (2016) analysed the geography of crime in Poland and its relationship to other fields of study. According to Maik (1995), two basic directions can be distinguished in crime research: one based on statistical data on various kinds of crimes, and another referring to sociology and the feeling of safety in 
society - the subjective character of the phenomenon. Research based on detailed data on the location of crimes aims to locate the occurrence of crime and the scale and dynamics of the phenomenon. Such research evidences that population density is the primary factor determining crime (Bogacka 2011). Studies regarding Poland apply simple indices concerning the number or intensity of crimes. Advanced mathematical-statistical analyses are scarce. An example of the application of a more advanced statistic is the paper by Mordwa, who employed the Wrocław taxonomy in his research (after Runge 1992), presenting typologies of cities by crime rate. Bogacka (2009) used multiple regression, correlating crime with the level of urbanisation, unemployment, wealth and population density. Other Polish researchers, such as Szymańska and Pappelbon, Wendt, and Bajerski, pointed to a correlation between the crime rate and the type of building development, as well as a decrease in the crime index with growing distance from the city centre. In his paper on Gdańsk, Wendt (2001) evidenced that the highest crime rate corresponds to places with a commercial character, located on the main transport routes. A paper by Bajerski (2006) showed that the highest crime rate occurs in the city centre, and particularly in areas with old neglected tenement house developments. Moreover, crime was also determined to be a problem for the inhabitants of particular streets and districts. Szymańska and Pappelbon (2001) draw attention to the fact that "the higher crime rate in certain parts of the city is related to the inappropriate architectonic form and bad organisation of the district". In his numerous works, Mordwa (2003, $2007,2010,2011,2012$ ) analysed criminality and the perception of living safety at the regional and general state level in Poland.

\section{Study area}

With a population of 326,000 , Lublin is the largest city in Poland east of the Vistula River. It is also one of the oldest cities in Poland. Its genesis is frequently associated with the period of creation of the Polish state. It is currently among the centres in Poland with a decreasing population. Since 1999, the number of residents has decreased by almost 25,000 . From both a social and a scientific point of view, this is a disturbing phenomenon. The city is located approximately $100 \mathrm{~km}$ from the border with Ukraine, also constituting the eastern border of the European Union. Due to the tight character of the border, the entire Lublin region has the classic features of a peripheral region, with limited possibilities for cross-regional cooperation. On the other hand, the city receives large groups of immigrants from Eastern Europe, both legal and unregistered, searching for better educational and work possibilities. As a city with a relatively low cost of life, it also receives many students from the Arabian countries and South and South-East Asia. Due to its nine higher education institutions, including five large state universities, among them the Medical University, the contribution of foreigners to the total number of students is continuously growing.

In recent years, Lublin has been transformed from a somewhat dormant city into quite an active cultural centre with a rich nightlife, attracting an increasing number of tourists from Poland and abroad. Simultaneously, the public opinion signals problems related to the safety of users of the urban space. For these reasons, detailed research has been undertaken concerning crime in the territory of Lublin. The research was also provoked to a certain degree by the city's ambition to follow the path of sustainable development. The diagnosis of the level of safety may therefore have not only a purely cognitive, but also an applicative nature. It can provide the basis for undertaking specific corrective measures in relation to consciously conducted urban policy.

An interesting starting point for our research was a paper by Mordwa (2003), which developed a typology of Polish cities by crime rates by means of the Wrocław taxonomy. According to the typology, Lublin belongs to the "relatively safe" cities with an average number of crimes, average detectability, and low rate of crime increase. Other publications from the early $21^{\text {st }}$ century also evaluated Lublin as one of the safest provincial centres in Poland (Siemaszko 2008; Jabkowski \& Kilarska 2013). The level of safety was manifested in figures concerning crimes such as car theft or number of murders (Reid 2000). In comparison to other cities in Poland, such crimes were characterised by low numbers at the turn of the century.

According to another study conducted by Siemaszko (2009), however, only around $42.1 \%$ of committed crimes are reported in Lublin, and the ratio of reported events is one of the lowest in the country $(47.5 \%$ for Poland). Theft is reported the least often (with the exception of car theft) - the report ratio for Poland is $39.7 \%$, and for the Lubelskie Voivodeship $42.3 \%$. Battery is the least often reported crime threatening life and health $-36.9 \%$. In one in three cases, failure to report crimes to law enforcement authorities in Poland is caused by victims regarding the event as not sufficiently serious to be reported. Lack of faith in catching the perpetrator accounts for just over $20 \%$ of cases. In more than half of cases, failure to report a committed crime is related to the general evaluation of the work of the police.

\section{Data and methods}

This work uses statistical data from the Voivodeship Police Department in Lublin (to evaluate the criminality and its spatial changeability in general and according to its main categories, such as theft, battery, mugging, criminal damage, robbery and homicide) and materials from our own field research (to evaluate the safety of inhabitants and its determinants). In order to elaborate the statistical data collected from the Voivodeship Police Department in Lublin, cartographic and statistical methods of spatial distribution of criminality were used, such as the CrimeAnalyst plug-in for ArcGIS and Corel Draw. The assessment of the feeling of safety of the inhabitants of Lublin city and its determining factors involved the development of a special questionnaire including 33 detailed questions. The questionnaire was composed of three parts: part A (demographic) - concerning general information about the respondents (6 detailed questions); part $\mathrm{B}$ - concerning issues of the quality and level of life of inhabitants of Lublin (10 detailed questions); part $\mathrm{C}$ - concerning the level of safety in places of residence (18 questions). The survey was conducted in May 2012 in all districts of Lublin with a random (based on circumstances) selection of respondents. The field research was conducted with the division of the city of Lublin into 15 districts, based on the historical conditions existing in Lublinians' consciousness. A total of 589 people belonging to each administrative district of Lublin city completed the survey questionnaire, making the data representative for the whole city. From the questionnaires, 526 were selected for further analysis based on their completeness. The number of conducted questionnaires in each city district ranged from 20 to 58 (most districts were represented by 25-35 respondents). The unequal sample of respondents in different city districts did not affect the quality of the research, considering the main aim of the research was to evaluate inhabitants' safety not for a concrete district or housing residence, but for the Lublin city space in general. The collected information provided the basis for the development of a database permitting the operation of a large set of data. The collected data was processed using MS Excel and STATISTICA software. Statistical analysis in relation to the qualitative parameters was performed with the application of the chi-square test and C-Pearson contingency coefficients for the determination of correlations between the analysed dependent variables - feeling of safety in place of residence, perception 
MISCELLANEA GEOGRAPHICA - REGIONAL STUDIES ON DEVELOPMENT

Vol. $21 \cdot$ No. 1 • 2017 • pp. 25-34 • ISSN: 2084-6118 • DOI: 10.1515/mgrsd-2017-0002

Table 1. Characteristics of the surveyed population in Lublin, $N=526$

\begin{tabular}{|c|c|c|}
\hline Group of features & Feature & Share of respondents, $\%$ \\
\hline \multirow{2}{*}{ Gender } & female & 58.2 \\
\hline & male & 41.8 \\
\hline \multirow{4}{*}{ Age } & $19-24$ & 24.6 \\
\hline & $25-35$ & 20.3 \\
\hline & $36-60$ & 36.2 \\
\hline & above 60 & 18.9 \\
\hline \multirow{3}{*}{ Marital status } & unmarried & 32.9 \\
\hline & married & 56.4 \\
\hline & other & 10.7 \\
\hline \multirow{8}{*}{ Employment status } & working in private sector & 26.6 \\
\hline & working in public sector & 17.3 \\
\hline & self-employed & 10.1 \\
\hline & farmer & 0.8 \\
\hline & unemployed & 8.7 \\
\hline & benefits recipients & 4.9 \\
\hline & old-age pensioner & 17.1 \\
\hline & student & 18.8 \\
\hline \multirow{3}{*}{ Educational status } & basic education & 6.5 \\
\hline & secondary education & 51.9 \\
\hline & higher education & 40.9 \\
\hline \multirow{3}{*}{ Income self-evaluation } & insufficient for basic needs & 23.9 \\
\hline & sufficient for basic needs & 55.3 \\
\hline & sufficient for basic needs and other additional expenses & 20.8 \\
\hline
\end{tabular}

Source: own elaboration

of dangerous areas, and safety precautions - and dependent variables, such as age, gender, level of income, victimizing experience, health self-evaluation, place of residence, and living conditions. The characteristics of the surveyed population are presented in Table 1.

Among the respondents there was a slight predominance of women (58.2\% of the entire group). The highest number of respondents were aged $36-60$ (36.2\% of the total number of respondents), and the lowest number was represented by people aged 60 and older (approximately 20\%). Considering the specificity of the research subject and the nature of the social structure of Lublin, an untypical division into age groups was applied here. A group of students was designated, constituting almost a quarter of the population of Lublin (aged 19-24). The group of professionally active people was divided into two categories: up to 35 years of age, and older. The former is characteristic of people with higher cultural and entertainment activity, which may be of relevance to research on crime. In the conducted research, the majority of respondents were married or single. The third group constituted people currently divorced or widowed. In terms of professional activity, people employed in the private and public sectors were predominant, as well as old-age pensioners and students. People with secondary (36\%), incomplete higher $(13.9 \%)$, and higher education were dominant $(27 \%)$. The diversity of education largely determines the manner of satisfying people's basic needs, the consumption model, and people's approach to their own health and life. Respondents were distinguished by a very low and low level of wealth (approximately $24 \%$ of people declared that their income is insufficient to meet even basic needs, and $55 \%$ had income sufficient only for satisfying basic needs). In the spatial aspect, inhabitants of the following districts assessed their material situation at the lowest level: Śródmieście, Wrotków, and Kalinowszczyzna (with the highest proportion of people in the total number of respondents with income insufficient to satisfy even basic needs), and at the highest level - Czechów, LSM, Sławin, and Sławinek (the highest proportion of people with income sufficient for basic needs and other additional expenses was recorded in these districts). The structure of respondents' incomes was dominated by income from work (approximately $53 \%$ ), followed by old-age pensions (18.3\%), stipends $(8 \%)$, unemployment benefits, and other social benefits (9\%). Approximately $5.7 \%$ of respondents reported no income. This may suggest that these people are supported financially by other people. Respondents' level of wealth largely determines their manner of spending free time: only one in three respondents practices active recreation, whereas on in four spends their free time watching TV.

Results

Level of crime in Lublin in the context of police records

Crimes in Lublin constitute $2 \%$ of all crimes committed in Poland. According to police statistics, in 2010 in Lublin, 313 crimes occurred for every 10,000 residents. According to the literature on the subject, at the same time in Katowice the index was 520, in Kraków 430, and in Białystok only 170. In comparison to other provincial centres, the level of crime in Lublin remains average.

In the spatial aspect, the highest number of criminal events occur in the central part of the city, particularly in the Śródmieście district. Approximately $26 \%$ of all crimes in the city were committed in this district. This is directly related to the high concentration in the area of cultural and entertainment venues. This is where the organisation of mass events takes place, and where three quarters of all gastronomic venues in Lublin are situated. Another district with a high proportion of the total number of crimes is 
Rury (which covers the area of the Lublin Housing Cooperative LSM). Its contribution, however, amounts to less than $10 \%$ of all crimes (less than half the amount in Śródmieście). The number of crimes in other districts directly neighbouring Śródmieście, such as Kalinowszczyzna, Czechów Południowy, Wieniawa, and Czuby Północne, remains at a similar level, although they differ in social terms. One characteristic feature is a decreasing proportion of crime with growing distance from the central part of the city. Crime rate is also closely correlated with population density (Fig. 1). It can be observed that, in the districts with the highest population density, the highest number of events are registered by the Police. This feature is common to districts such as Rury, Wieniawa and Kalinowszczyzna. These are zones of tall blocks from the 1970s and 1980s. Thefts are dominant there, while many cases of mugging are also recorded. The districts with low population density are characterised by the lowest number of crimes. In these districts, particularly those with single family houses, there is a high proportion of burglary and theft (e.g. in Zemborzyce or Ponikwoda).

A specific exception to these correlations is the Dziesiąta district. A relatively high number of crimes are recorded there, despite its low population density and considerable distance from the city centre. It includes a zone of pre-war, degenerated tenement houses inhabited by people with a high level of unemployment and low income.

Expressing the number of criminal offences per number of residents in a given district shows the effect of the distribution of the population, but also the function of a given district. The ratio of committed crimes per 1,000 residents is the highest in the centre (Śródmieście and Stare Miasto districts), but also in the Za Cukrownią, Zemborzyce and Hajdów-Zadębie districts. The ratio varies from 31 to 63 events per 1,000 residents in the area.

Perception of safety by residents of Lublin in the context of the survey

An important determinant in the assessment of the studied phenomena of crime and safety in the city is the quality of life of the inhabitants. According to our research, only $65 \%$ of respondents assess their quality of life as very good or good, whereas $7 \%$ assess it as bad or very bad. The respondents were also asked about their degree of satisfaction with living in Lublin. Among all the respondents, people satisfied with living in Lublin were predominant (almost $70 \%$ of respondents). Only one in ten people showed no satisfaction. When divided into districts, respondents from the following districts were the most satisfied: Czuby (84.2\% of respondents), Kalinowszczyzna and Lipniak, and the least satisfied: Piaski (55.6\% of respondents), Czechów and Bronowice. Respondents were also asked about their degree of satisfaction with their particular place of residence and living conditions. It turned out that a large majority of respondents are satisfied with their place of residence (approximately 76.4\%) and living conditions $(77.4 \%)$. The total contribution of people very dissatisfied and rather dissatisfied with these aspects was approximately $10 \%$ in the case of assessment of place of residence, and approximately $12 \%$ in the case of assessment of living conditions. The statistical analysis showed the existence of a moderate correlation between the satisfaction of respondents with living in Lublin and their district of residence (significance level $p=0.0015$ at a C-Pearson coefficient value of 0.323 ).

According to research from the Centre for Public Opinion Research, conducted in 2014 in Poland, more than two fifths of Poles (almost $45 \%$ ) expressed fear of becoming a victim of crime (Komunikat z badań CBOS 2014). In our research, approximately $26 \%$ of the inhabitants of Lublin participating in the survey assessed the situation in terms of safety as bad or rather bad, whereas only $39 \%$ considered the situation as good or rather good (Fig. 2).

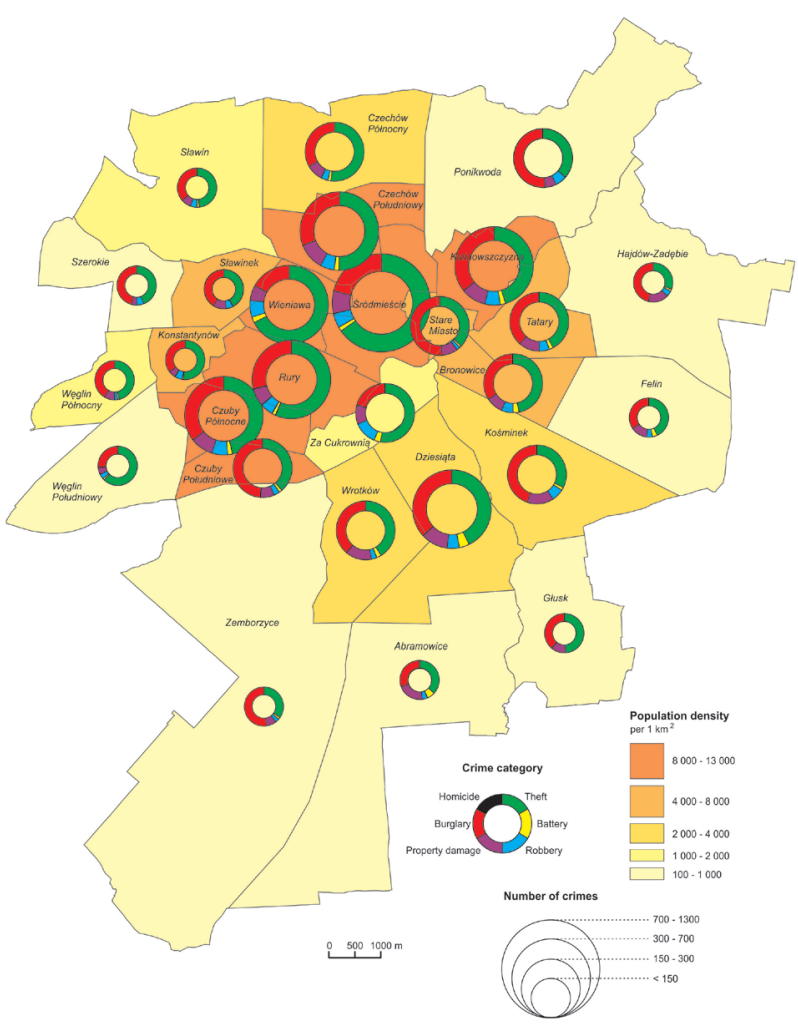

Figure 1. Structure of crimes by districts in Lublin Source: Own elaboration based on data from the Voivodeship Police Department in Lublin

Evaluation of safety in Lublin, according to respondents, \%

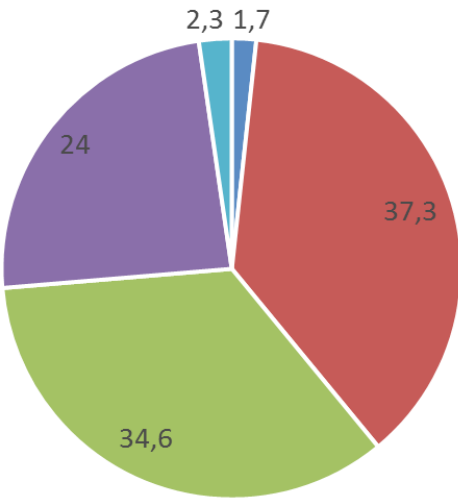

" very good " quite good " hard to say "quite bad " verybad

Figure 2. Evaluation of safety in Lublin, 2012

Source: own elaboration

On the contrary, Ceccato and Lukyte (2011), who studied the city of Vilnius in Lithuania, showed that nearly $67 \%$ of respondents declared that they felt unsafe in their place of residence.

According to our research, older people evaluated their safety situation at the lowest level (approximately $35.4 \%$ of the analysed group of respondents), and people aged 24 or less evaluated it at the highest level (17.1\% of respondents). People 
with a low education level, as well as those with a marital status other than unmarried or married, feel less safe in the city than the best educated and unmarried people. Respondents were also asked about the dynamics of the changes in the safety situation in Lublin over the last 10 years. The highest contribution of respondents (approximately 35\%) believes that the situation has not changed, while $30 \%$ of respondents declared that the situation has improved. One in four respondents state, however, that safety conditions in Lublin have deteriorated over the last decade. Research conducted by Jabkowski and Kilarska (2013) shows that, in the period $2000-2010$, both the number of crimes and the index per 10,000 residents decreased from 404 to 313 .

The respondents were also asked a number of questions concerning their perception of the safest and most dangerous districts and types of areas in Lublin, their victimization experience, and types of measures applied for securing themselves and their properties against crimes.

Districts of single family houses and new block districts are considered the safest types of areas by the majority of respondents. In spatial terms, respondents evaluated districts of Lublin such as LSM, Czuby and Sławinek as the safest. This only partly corresponds with the data of Police statistics (Table 2). LSM is part of the Rury district, which according to Police data belongs to a zone characterised by a rather high number of crimes per year. This area, however, has a very good reputation regarding living conditions, originating from past times. It was the first post-war district of Lublin, with very high urban planning and architectonic standards as per the Socialist reality, dominated by low blocks of flats, and with a high proportion of arranged recreational areas. It was inhabited by a group of intellectuals from Lublin involved in the organisation of the social space. A real community was created there. Over more than 40 years, flats in the district maintained high prices, constituting a barrier to the inflow of population with a lower social status, usually accompanied by unfavourable phenomena. Moreover, due to its high quantity of green areas, LSM was known as an oasis of peace and quiet. Such features probably contributed to the common assessment of the level of safety in the area. It should be emphasised, however, that calculations of the total number of crimes per number of residents in both Rury and Czuby provide quite low indices of crime: approximately 10 and 20 crimes per 1,000 residents, respectively. Therefore, the good opinion results not only from stereotypes, but also from the lack of negative experiences of a major part of the residents.

The central and eastern industrial districts were recognised as dangerous, including Śródmieście, Kalinowszczyzna, Bronowice, Dziesiąta, and Tatary (Table 3). Interestingly, in the awareness of the residents, it is not Sródmieście that is the most dangerous, but predominantly Tatary, followed by Bronowice and Dziesiąta. Similar findings emerged in the work of Ceccato and Lukyte (2011) based in Vilnius city centre, which is perceived as a relatively safe place. Criminal events recorded in the Śródmieście district in Lublin are closely related to the entertainment function of the area. Victims of crimes are largely visitors from outside Lublin. Therefore, the surveyed residents of the city consider the district as safer than it really is. Moreover, in recent years, Śródmieście has undergone a major revitalisation. The appearance of the buildings has improved, probably contributing to a better image in terms of safety. The Tatary district, constituting the most dangerous part of Lublin in the opinion of almost $60 \%$ of respondents, is among the moderately dangerous zones of the city according to Police statistics. Similarly to Bronowice, Kalinowszczyzna and Dziesiąta, it is a workers' district where very serious crimes have happened in the past. As it turns out, memory of negative phenomena is longlasting. Moreover, it can be noted that the districts are located in the group of areas in which murders occur nowadays.
Table 2. The safest districts and types of residential areas in Lublin according to the respondents, $N=526$

\begin{tabular}{|c|c|}
\hline Districts of residential areas & Share of respondents \\
\hline LSM & 31.9 \\
\hline Czuby & 23.8 \\
\hline Sławin and Sławinek & 28.5 \\
\hline Types of residential areas & \\
\hline Single-family housing & 70.3 \\
\hline New blocks of flats & 38.2 \\
\hline Old blocks of flats & 5.7 \\
\hline
\end{tabular}

Source: own elaboration

Table 3. The most dangerous districts and types of residential areas in Lublin according to the respondents, $N=526$

\begin{tabular}{|c|c|}
\hline Districts of residential areas & Share of respondents \\
\hline Śródmieście & 19.2 \\
\hline Kalinowszczyzna & 19.8 \\
\hline Bronowice & 37.3 \\
\hline Dziesiąta & 20.3 \\
\hline Tatary & 57.2 \\
\hline
\end{tabular}

Source: own elaboration

The most dangerous areas by night (mentioned by more than 30 respondents) included the Dziesiąta district, Lubartowska, Kunickiego, Krochmalna and Grygowej streets, as well as the vicinity of the bus and train stations, bus stops, city parks, and the cycling path along the Bystrzyca River. In the opinion of the majority of respondents, places dangerous by day include the vicinity of Krochmalna and Nadbystrzycka streets, areas surrounding blocks of flats, city gates, vicinities of social buildings, the market at Ruska Street, and the blocks of flats in an emergency state in the Dziesiąta district.

For the entire group of respondents, the greatest fear resulted from the probability of the respondent being subject to theft (64\% of respondents) or battery (approximately $38 \%$ of respondents). Other types of threats mentioned by inhabitants of Lublin usually included mugging, damage to property, and burglary (Fig. 3). Whereas fear of theft seems to result from a high occurrence of this type of crime in the territory of Lublin, fear of battery finds no proper justification in terms of the police statistics. It is probable, however, that cases of battery do occur, but they are not reported to the police.

Inhabitants of Lublin were more afraid for their property than of a physical attack. The greatest fear regarding murder was observed among the surveyed residents of the following districts: Wrotków, Felin, Śródmieście and Kalinowszczyzna. Fear of battery was dominant among residents of Śródmieście, Dziesiąta, Sławin and Sławinek, as well as Kalinowszczyzna and Czechów. Fear for property was usually reported by residents of Kalinowszczyzna, Śródmieście, Węglin, Sławin and Sławinek, as well as Tatary and Czechów. The research showed that the general risk of threat of crime depends on the district of a given resident. No evident spatial variability was revealed, however, in terms of types of threat depending on dangerous residential districts.

When asked about being victim to a crime over the last 10 years, almost $30 \%$ of respondents provided a confirmative answer. Types of crimes to which respondents were victim were 
Most frequent dangers in Lublin, according to respondents, \%

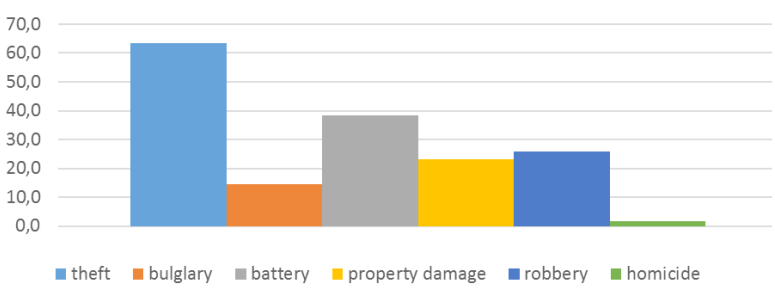

Figure 3. Fear of being victimized by crime in Lublin in 2012, \% Source: own elaboration

dominated by theft (19.6\%), property damage $(5.1 \%)$ and battery (4.4\%). The question regarding the assessment of the activity of the Police and municipal guards was answered positively in only $14 \%$ of cases, whereas $23 \%$ of respondents provided a negative answer. When divided into districts, the activity of the police and municipal services was evaluated the worst by residents of the districts most threatened by crime, namely Dziesiąta (13.8\%), Kalinowszczyzna and Śródmieście. Interestingly, Kalinowszczyzna is simultaneously distinguished by the highest proportion of people (in comparison to other districts of Lublin) positively assessing the activity of these services (almost $20 \%$ of respondents). One in ten respondents believe that their place of residence has an unfriendly, anonymous atmosphere. A particularly high percentage of such respondents was observed in the following districts: Bronowice (almost 21\%), Śródmieście and Tatary (13\% each). The two-variable analysis of the victimization experience of respondents showed no statistical correlation with their socio-demographic parameters, such as age, gender, marital status, education level or income. A statistically significant correlation was only determined between victimization experience and leaving home after dark (significance level $p=0.00009$ at the C-Pearson's coefficient value of 0.208 ), which means that crimes are particularly committed by night.

Respondents were also asked about types of measures they used to protect themselves and their property against crimes. These measures were divided into 2 groups:

- direct preventive: carrying items for defence when leaving home, stepping out of the way of certain groups, avoiding certain places and streets, staying at home after dark;

- indirect preventive: participation in a self-defence course, additional security measures in the home, property insurance, having a dog.

The most common precautions undertaken by respondents for the purpose of securing themselves and their property against crimes included avoiding dangerous places and streets, additional security measures in the home, and property insurance (Table 4).

The behaviours differ considerably depending on the age, gender, marital status and material status of those surveyed (Table 5).

Direct preventive measures were more likely to be undertaken by women, elderly people (over 60 years of age), lonely people, and people with a lower education and material status. Indirect preventive measures concerned men, mature people (35-60 years of age), married people, those with a high education status, and those with an average or higher income level to a greater extent.

In the two-variable analysis, the feeling of safety of selected Lublin residents depended on the place of residence to some extent (significance level $p=0.00253$ at C-Pearson's contingency coefficient of 0.431 ), self-evaluation of life quality (significance
Table 4. Safety precautions most frequently chosen by respondents from Lublin to protect their property and themselves, $N=526$

\begin{tabular}{|c|c|}
\hline Type of security measures & Share of respondents, \% \\
\hline $\begin{array}{c}\text { Participation in a self-defence } \\
\text { course }\end{array}$ & 6.8 \\
\hline Carrying precaution devices & 10.3 \\
\hline $\begin{array}{c}\text { Stepping out of the way of certain } \\
\text { groups of people }\end{array}$ & 37.8 \\
\hline $\begin{array}{c}\text { Avoiding certain places and } \\
\text { streets }\end{array}$ & 53.6 \\
\hline Avoiding leaving home after dark & 19.0 \\
\hline Having a dog & 19.2 \\
\hline Additional home safeguards & 24.7 \\
\hline Property insurance & 27.8 \\
\hline
\end{tabular}

Source: own elaboration

Table 5. Measures of self- and property protection in the context of selected features of respondents in Lublin, $N=526$

\begin{tabular}{|c|c|c|c|c|c|c|c|c|}
\hline $\begin{array}{c}\text { Features of } \\
\text { respondents }\end{array}$ & 1 & 2 & 3 & 4 & 5 & 6 & 7 & 8 \\
\hline \multicolumn{9}{|c|}{ Gender } \\
\hline Men & \begin{tabular}{|l|}
47.2 \\
\end{tabular} & 59.3 & 34.2 & 34.4 & \begin{tabular}{|l|}
19.0 \\
\end{tabular} & 51.5 & 35.4 & 43.2 \\
\hline Women & 52.8 & 40.7 & 65.8 & 65.6 & 81.0 & 48.5 & \begin{tabular}{|l|}
64.6 \\
\end{tabular} & 56.9 \\
\hline \multicolumn{9}{|c|}{ Age in years } \\
\hline $19-24$ & 44.4 & 35.2 & 26.1 & 24.5 & 7.0 & 14.9 & \begin{tabular}{|l|}
17.7 \\
\end{tabular} & 12.3 \\
\hline $25-35$ & 30.6 & 31.5 & 19.6 & 24.5 & 13.0 & 25.7 & 21.5 & 21.9 \\
\hline $36-60$ & 25.0 & 31.5 & 31.2 & 36.5 & 30.0 & 40.6 & 40.0 & 48.6 \\
\hline More than 60 & 0.0 & 1.9 & 23.1 & 14.5 & 50.0 & 18.8 & 20.8 & 17.1 \\
\hline \multicolumn{9}{|c|}{ Marital status } \\
\hline Unmarried & 47.2 & 55.6 & 35.2 & 33.3 & \begin{tabular}{|l|}
12.0 \\
\end{tabular} & 27.7 & 18.5 & 19.2 \\
\hline Married & 44.4 & 40.7 & 51.3 & 57.1 & 57.0 & 60.4 & 67.7 & 71.9 \\
\hline Other status & 8.3 & 3.7 & 13.6 & 9.6 & 31.0 & 11.9 & 13.9 & 8.9 \\
\hline \multicolumn{9}{|c|}{ Education } \\
\hline Basic & 0.0 & 0.0 & 8.1 & 5.7 & \begin{tabular}{|l|l|}
15.0 \\
\end{tabular} & 6.9 & 6.2 & 6.8 \\
\hline $\begin{array}{c}\text { Basic } \\
\text { vocational and } \\
\text { secondary }\end{array}$ & 48.9 & 51.9 & 53.8 & 48.9 & 55.0 & 57.4 & 40.8 & 44.5 \\
\hline $\begin{array}{l}\text { Incomplete } \\
\text { higher and } \\
\text { higher }\end{array}$ & 58.3 & 48.1 & 37.7 & 45.4 & 30.0 & 35.6 & 53.1 & 48.6 \\
\hline \multicolumn{9}{|c|}{ Self-evaluation of income } \\
\hline $\begin{array}{c}\text { Not sufficient } \\
\text { for basic } \\
\text { needs }\end{array}$ & 23.8 & 23.8 & 23.8 & 23.8 & 23.8 & 23.8 & 23.8 & 23.8 \\
\hline $\begin{array}{l}\text { Sufficient for } \\
\text { basic needs }\end{array}$ & 55.1 & 55.1 & 55.1 & 55.1 & 55.1 & 55.1 & 55.1 & 55.1 \\
\hline $\begin{array}{l}\text { Sufficient for } \\
\text { basic needs } \\
\text { and other } \\
\text { additional } \\
\text { expenses }\end{array}$ & 20.7 & 20.7 & 20.7 & 20.7 & 20.7 & 20.7 & 20.7 & 20.7 \\
\hline
\end{tabular}

1 - participation in a self-defence course, 2 - carrying items for defence when leaving home; 3 - stepping out of the way of certain groups; 4 - avoiding certain places and streets; 5 - staying at home after dark; 6 - having a dog; 7 - additional security measures for property; 8 - property insurance.

Source: own elaboration 
level $p=0.01645$ at the C-Pearson's coefficient of 0.284 ), and self-evaluation of health (significance level $p<0.000001$ at the C-Pearson's coefficient of 0.365 ), as well as victimization experience (significance level $p<0.000001$ at the C-Pearson's coefficient of 0.299). No statistically significant correlation was found between the feeling of safety and the age, gender, marital status, or self-evaluation of material and educational status of respondents. The correlation between the feeling of safety and health probably results from the effect of the age of respondents, and life quality from respondents' incomes.

\section{Discussion of results}

The conducted research on crime in Lublin confirms the majority of conclusions from the literature on the subject. As in other large cities, crimes against property are evidently dominant over those against life and health (compare Jabkowski 2008). According to Ceccato (2002) and Bogacka (2011), the greatest density of crimes occurs in the city centre, followed by the most densely populated areas, particularly those with unfavourable social phenomena. The correlation between the number of crimes and the type of building development, as emphasised by Szymańska and Pappelbon (2001) Wendt (2001) and Bajerski (2006), was also confirmed. Areas with old, low buildings, including tenement houses, underinvested in terms of infrastructure, are the zones with a higher than average threat index. The high number of crimes in the Rury district is surprising. This is an area with a high population density, but it is dominated by building developments with high technical and aesthetic standards. In the opinion of residents, it is one of the safest zones in the city. The high crime rate can be explained by the presence in the area of several large supermarkets and commercial centres. Research by other authors suggests a correlation between these phenomena (Wendt 2001).

A certain similarity to the results of other studies was also recorded at the stage of searching for the variables determining the feeling of safety. Our study results partly correspond with research by Jabkowski (2008) conducted in Poznań on the correlation between participants' general feeling of safety and their self-evaluation of their state of health and life satisfaction (synonymous to quality of life). In contrast to the research conducted in Poznań, in the case of Lublin, correlations between the feeling of safety and the gender, age and income of the population were not confirmed. Research conducted in Łódź by Marcińczak and Siejkowska (2003) also showed no correlation between the perception of dangerous areas and the social and demographic diversity of respondents. As in Jabkowski's research, one of the most important factors differentiating people's perceptions of safety in the city is previous direct and indirect victimization experience. In our research, the most important factor differentiating residents' levels of safety perception is their district of residence, whereas in the case of Poznań no such correlation was recorded (Jabkowski 2008). Similarly to research concerning the residents of Łódź (Marcińczak \& Siejkowska 2003), in Lublin, the areas perceived as the most dangerous included the city centre, areas with tenement houses, and narrow streets. The prevalence of residents of Lublin undertaking defensive measures for the purpose of protecting themselves and their properties was significantly correlated with the financial situation of the respondents and their level of education. Our study results are also partly reflected in research by Mordwa (2011) regarding the feeling of safety in Łódź, and in research by Ceccato and Lukyte (2011) regarding safety in Vilnius (Lithuania).

\section{Conclusions}

The research suggests that Lublin is rightly considered to be a relatively safe city. The registered crime rate remains at an average level for Polish conditions. In the period 2000-2010, the crime rate decreased by $25 \%$. This means that the inflow of foreigners to the city has no negative impact on the sphere of safety.

The analysis of data on crime in Lublin shows the existence of a clear zone of increased risk of the occurrence of crime in the territory of the city. It covers the city centre, including the Stare Miasto and Śródmieście districts. The area dominates in criminal statistics, both in terms of general number of crimes and regarding the number of residents and surface area. This makes it the area with the highest criminal threat. A high number of crimes is also characteristic of other districts located in the immediate vicinity of Śródmieście, although they represent different social profiles. They are, however, districts with high population density, which seems to justify the scale of the phenomenon. The comparison of the number of crimes and number of residents shows that, apart from Śródmieście and Stare Miasto, the crime indices highlight districts with pre-war, degenerated tenement houses inhabited by a population with a high level of unemployment and low income. This group also includes a peripheral district fulfilling recreational functions for the residents of the city and nearby communes.

The actual level of crime and its spatial distribution is somewhat different than that perceived by residents. Less than $30 \%$ of residents have noticed an improvement in the level of safety. A large group of respondents (approximately $25 \%$ ) perceives the situation as deteriorating. Considering the conclusions from the analysis of the social conditions of respondents' feelings of safety, this image presumably results from a deterioration in the quality of life or health of the respondents, or their negative experiences. These are the factors determining Lublin residents' perceptions of the safety status to the greatest degree. The feeling of danger in Lublin may also be determined by the general increase in danger on the global scale. The awareness of growing crime rates in various parts of the world increases personal feelings of threat and negatively affects the assessment of the immediate living environment.

The image of the level of safety in particular districts is also disturbed. The most dangerous district, namely Śródmieście, occupies fifth place in the assessment of residents. The first four positions in the ranking of districts with the highest level of threat are former workers' districts - both from the early $20^{\text {th }}$ century and from the post-war period. This situation has two main causes: bad reputations resulting from high crime levels in the past, and the fact of the occurrence of the most serious crimes - murders - in these areas. Threat to life results in a more negative image than the threat of loss of property.

Certain thinking patterns also determine the selection of the safest districts. The top places in the ranking by residents are occupied by those that had good reputations in the past, not only in terms of safety, but also quality of life and the attractiveness of the building developments. This confirms the conclusion that the subjective perception of reality is only fragmentarily reflected in the image based on facts.

Taking into consideration modern political changes and the increased number of immigrants to Lublin city, mainly from Ukraine which is now facing military conflict, we are planning to repeat our research in order to determine the directions and tendencies of modern changes in criminality and perceived safety by the inhabitants of the city. 
Ackerman, W \& Murray, A 2004, 'Assessing Spatial Patterns of Crime in Lima, Ohio', Cities, vol. 21, no. 5, pp. 423-437.

Andresen, MA 2009 'Crime in Lithuania: The impact of accession to the European Union', European Journal of Criminology, vol. 6 , no. 4, pp. 337-360.

Ashby, D \& Craglia, M 2007, Profiling places: geodemographics and GIS, in Handbook of Criminal Investigation, eds T Newburn, T Williamson and A Wright, Willan Publishing, Cullompton, pp. 517-546.

Bajerski, A 2006, Zróżnicowanie przestrzenne przestępczości w Poznaniu in Przemiany przestrzeni miast i stref podmiejskich, eds J Słodczyk \& R Klimek, Wydawnictwo Uniwersytetu Opolskiego, Opole, pp. 263-272.

Bogacka, E 2009, Przestępczość w Poznaniu, in Biuletyn Instytutu Geografii Społeczno-Ekonomicznej i Gospodarki Przestrzennej UAM, Seria Rozwój Regionalny i Polityka Regionalna, eds JJ Parysek, no. 6, Bogucki Wydawnictwo Naukowe, Poznań, pp. 87-100.

Bogacka, E 2011, Współczesny dorobek światowych i polskich badań przestrzennych aspektów przestępczości, in Gospodarka przestrzenna XXI wieku, eds S Kornik \& Z Przybyła, Wydawnictwo Uniwersytetu Ekonomicznego, Wrocław, pp.13-24.

Ceccato, V \& Bamzar, R 2016 'Elderly Victimization and Fear of Crime in Public Spaces', International Criminal Justice Review, vol. 26, no. 2, pp. 115-133.

Ceccato, V \& Lukyte, N 2011 'Safety and sustainability in a city in transition: The case of Vilnius, Lithuania', Cities, vol. 28, no. 1, pp. 83-94. Available from: <http://dx.doi.org/10.1016/j. cities.2010.10.001>. [11 November 2016].

Ceccato, V 2008 'Expressive Crimes in post-socialist states of Estonia, Latvia and Lithuania', Journal of Scandinavian Studies in Criminology and Crime Prevention, vol. 9, no. 1, p. 2-30.

Ceccato, V, Haining R \& Signoretta, P 2002, 'Exploring Offence Statistics in Stockholm City Using Spatial Analysis Tools', Annals of the Association of American Geographers, vol. 92, no. 1, pp. 29-51.

Chainey, S \& Ratcliffe, J 2005, GIS and Crime Mapping, John Wiley \& Sons Ltd, Chichester.

Crawford, A 2006, Policing and community safety in residential areas: the mixed economy of visible patrols, in Housing, Urban Governance and Anti-Social Behaviour, eds J Flint, The Policy Press, Bristol, pp. 219-238.

Fajnzylber, P, Lederman, D \& Lloayza, N 2002 'Inequality and violent crime', Journal of Law and Economics, vol. 45, no. 1, pp. $1-40$.

Fyfe, NR 2000, Crime geography, in The Dictionary of Human Geography, eds R Johnston, D Gregory, G Pratt, D Smith \& M Watts, Blackwell, Oxford, pp.120-130.

Guzik R., 2000, 'Przestrzenny obraz przestępczości w prasie krakowskiej', Prace Geograficzne Instytutu Geografii UJ, no. 106, Kraków, pp.197-216.

Jabkowski, P \& Kilarska, A 2013, Poczucie bezpieczeństwa $i$ poziom przestępczości w Poznaniu. Mieszkańcy-samorząd lokalny-instytucje państwa, Wydawnictwo Naukowe UAM w Poznaniu, Poznań.

Jabkowski, P 2008, 'Poczucie bezpieczeństwa i przestępczości w Poznaniu. Analiza socjologiczna w perspektywie wskaźników jakości życia', in Zastosowanie metod statystycznych w badaniach naukowych III, StatSoft Polska, pp. 203-212. Available from: <http://www.statsoft.pl/czytelnia.html>. [6 June 2016].
Jackson, J 2004 'Experience and expression: Social and cultural significance in the fear of crime', British Journal of Criminology, vol. 44, no. 6, pp. 946-966.

Jackson, J 2008 'Bridging the social and the psychological in fear of crime research', in M Lee \& S Farrall (eds), Fear of Crime: Critical voices in an age of anxiety, pp. 143-167. Glasshouse Press. London.

Komunikat z badań CBOS, Warszawa, czerwiec 2014, no. 82/2014. Available from:<http://www.cbos.pl/SPISKOM. POL/2014/K_082_14.PDF>. [5 April 2016].

Madge, C 1997, 'Public Parks and the Geography of Fear', Journal of Economic and Social Geography, vol. 88, no. 3, pp. 237-250.

Maik, W 1995, Socio-spatial analysis of crime and delinquency. A case of Toruń, in Conference Papers 24. Urban and regional issues in geographical research in Poland and Italy, eds B Gałczyńska \& G Węcławowicz, Wydawnictwo PAN IGiPZ, Warszawa, pp. 91-98.

Malczewski, J \& Poetz, A 2005, 'Residential Burglaries and Neighborhood Socio-Economic Context in London, Ontario: Global and Local Regression Analysis', The Professional Geographer, vol. 57, no. 4, pp. 516-529.

Marcińczak, S \& Siejkowska, A 2003, Percepcja miejsc niebezpiecznych w Łodzi, in Funkcje metropolitalne $i$ ich rola w organizacji przestrzeni. XVI Konwersatorium wiedzy o mieście, eds I Jażdżewska, Wydawnictwo Uniwersytetu Łódzkiego, Łódź, pp. 203-208.

Mordwa, S 2003, Przestępczość w dużych miastach w Polsce (na przykładzie Łodzi), in Funkcje metropolitalne $i$ ich rola $w$ organizacji przestrzeni. XVI Konwersatorium wiedzy o mieście, eds I Jażdżewska, Wydawnictwo Uniwersytetu Łódzkiego, Łódź, pp. 209-217.

Mordwa, S 2007, 'Przestępczość w Tomaszowie Mazowieckim w latach 2002-2005' Acta Universitatis Lodziensis. Folia Geographica Socio-Oeconomica, no. 8, pp. 171-184.

Mordwa, S 2010, Poczucie bezpieczeństwa mieszkańców wybranych osiedli w Łodzi, in Wartościowanie współczesnej przestrzeni miejskiej, eds M Madurowicz, Wydział Geografii i Studiów Regionalnych Uniwersytetu Warszawskiego, Warszawa, pp. 307-316.

Mordwa, S 2011, Poczucie bezpieczeństwa w Łodzi. Przykład badań osiedli mieszkaniowych in Współczesne przemiany środowiska mieszkaniowego - wybrane problemy, SpaceSociety-Economy eds J Dzieciuchowicz, no. 10, Wyd. Department of Spatial Economy and Spatial Planning, Łodź, pp. 181-196.

Mordwa, S 2012, Ciemna liczba przestępstw. Przykład badań wiktymizacyjnych mieszkańców wybranych obszarów w Łodzi, in Kształtowanie przestrzeni mieszkaniowej miast. Shaping the Urban Residential Area, Space-SocietyEconomy, eds J Dzieciuchowicz \& L Groeger, no. 11, Department of Spatial Economy and Spatial Planning, Łódź, pp. 145-155.

Mordwa, S 2016, 'The geography of crime in Poland and its relationship with other fields of study', Geographia Polonica, vol. 89 , no. 2, pp. 187-202.

Pain, R 2001, 'Gender, race, age and fear in the city', Urban Studies, No. 38, no. 5-6, pp. 899-913.

Reid, ST 2000, Crime and Criminology. McGraw-Hill, Boston.

Runge, J 1992, Wybrane zagadnienia analizy przestrzennej w badaniach geograficznych, Wydawnictwo Uniwersytetu Śląskiego, Katowice. 
Siemaszko, A (ed.) 2008, Geografia występku i strachu, Instytut Wymiaru Sprawiedliwości, Warszawa.

Siemaszko, A 2009, 'Polskie badanie przestępczości 2007-2009. Analiza wybranych rezultatów', Archiwum Kryminologii PAN, Vol. XXXI, pp. 223-264.

Smith SJ, Pain R, Marston SA, \& Jones III JP (eds) 2010, The SAGE Handbook of Social Geographies, SAGE, Lon Angeles-London-New Delhi-Singapore-Washington DC.

Smith, SJ 1987, 'Fear of crime: beyond a geography of deviance', Progress in Human Geography, vol. 11, no. 1, pp. 1-23.

Szymańska, D \& Pappelbon, J 2001, Przestępczość w przestrzeni miejskiej na przykładzie miasta powiatowego Ostródy, in Miasto postsocjalistyczne- organizacja przestrzeni miejskiej i jej przemiany. XIV Konwersatorium Wiedzy o Mieście, eds I. Jażdżewska, Wydawnictwo Uniwersytetu Łódzkiego, Łódź, pp. 77-93.
Treadwell, J 2006 'Some personal reflections on Probation Training', Howard Journal of Criminal Justice, vol. 45, no.1, pp. $1-13$

Tuan, Y 1979, Landscapes of Fear, Blackwell, Oxford.

Valentine, G 1992, 'Images of danger: women's sources of information about the spatial distribution of male violence', Area, vol. 24, no. 1, pp. 22-29.

Wang, F \& Minor W 2002, 'Where the jobs are: employment access and crime patterns in Cleveland', Annals of the Association of American Geographers, vol. 92, no. 3, pp. 435-450.

Wendt, J 2001, Przestrzenne zróżnicowanie przestępczości w Gdańsku, in Geografia różnorodności, różnorodność w geografii, eds I Łęcka, Wydawnictwo Wydziału Geografii i Studiów Regionalnych UW, Warszawa, pp. 61-65. 